\title{
sciendo
}

\section{Father André Scrima - A New Kind of Fool for Christ}

\author{
MARIUS VASILEANU
}

The complex and often puzzling personality of Father André Scrima was misapprehended for a long time. This article discusses the reasons for such a misapprehension and offers some possible explanations for his paradoxical behaviour. An overview of the reception of Father Scrima's life and works shows a dynamic at work that can only generate optimism. His participation in the Burning Bush group at the Antim monastery in Bucharest was one of the most important formative experiences, where a wide cultural and scientific perspective was fused with an indepth religious experience. Father Scrima may be better understood if we consider him the first of a new kind of fools for Christ, a kind that is well-equipped to face the challenges of tomorrow.

Keywords: André Scrima, Daniil Sandu Tudor, The Burning Bush, foolishness for Christ, hesychasm

He was a man that would experience the enthusiasm of a child when a new decimal of a universal constant was discovered. He used to tame an unbroken sacred text in a generous hermeneutics by offering it the fire of certain astrophysical theories and blending them with the phenomenology of the opening one's heart in a hesychastic manner. Could this be the reason why the impressive erudition of Father André Scrima is still hard to accept and to understand in the Orthodox ecclesiastical environment? Our hypothesis that will be dealt with in the current paper is that all the things mentioned above are not enough to explain his misapprehension: most likely, Father André Scrima was the first person belonging to a new kind of fool for Christ.

\section{The reception of the Burning Bush - the dynamics over the past three decades}

The complex personality of Father André Scrima cannot be understood outside his formative experience as a member of the Burning Bush group. The group was founded in the 1940s at the initiative of Sandu Tudor, Father Benedict Ghiuș and Alexandru Mironescu. The group comprised learned clerics and laypeople, who would meet periodically at the Antim monastery

\footnotetext{
* Marius Vasileanu, PhD, independent researcher, OP 33, CP 89, Bucharest, Romania, marius.vasileanu@gmail.com.
} 
in Bucharest (1944-1949) to discuss cultural and religious issues and to pray together. The main preoccupation of the group was the hesychastic prayer. The group benefited from the spiritual guidance of Father John the Stranger, who had lived at the Optina Russian monastery. After the instauration of the communist regime, the meetings were officially forbidden, but the participants continued to gather discreetly at the Plumbuita monastery in Bucharest or in other participants' homes (Olga Greceanu, Constantin Joja, Vasile Voiculescu and, more often, Alexandru Mironescu). The meetings ended when the most important members were arrested (1958), charged for plotting against the regime - of course, a groundless accusation - and imprisoned. Some of them died in prison (e.g. Father Daniil Sandu Tudor, d. 1962), but others survived and subsequently led a discreet life.

During the communist regime, there was no personal or institutional coherent and structured effort to document and understand the phenomenon of the Burning Bush. Therefore, we will deal with the reception of the Burning Bush after 1989. An overview of the work carried out in the past three decades reveals a certain dynamics: the growing number of works is correlated with a more in-depth analysis of the phenomenon.

In the first years after the fall of communism, Romanian people had other priorities. The unveiling and understanding of details in recent history, mainly communist history, were hindered by people who had played an important part in the former regime and who were trying to hide their past. Thus, the access to the communist archives was offered quite late, and even later for archives of the Romanian Orthodox Church (hence ROC). But this is a phenomenon that recurred throughout history with many regime changes.

A similar delay can be observed in the case of the "living archives," who were only accidentally valued and with a certain lack of professionalism. Besides the actual poverty that persisted throughout the first post-communist decade - no technical means were available to the ordinary researcher - , it seemed like the presence of a number of people who had been an active part of the Burning Bush compensated or even pushed away any professional endeavour, be it mediatic, anthropologic or historical. We all lived in a certain inertia as if the main members of the Burning Bush who had survived the regime change had been immortal. Their spiritual influence on those who were called to receive it was exerted discreetly, as it was supposed to be. But there were few initiatives among the disciples to record their testimonies, which are, in fact, a way of strengthening the Spirit.

At the beginning of the 1990s, a great part of the Burning Bush members were still alive: Father Benedict Ghiuș (died in June 1990), Father Sofian Boghiu (d. 2002), Father Petroniu Tănase (d. 2011), Father Nicodim Bujor 
(d. 2011), Father Arsenie Papacioc (d. 2011), Father Dumitru Stăniloae (d. 1993), Father Roman Braga (d. 2015), Father Felix Dubneac (d. 2008), Father Vasile Vasilache (d. 2003), Metropolitan Antonie Plămădeală (d. 2005), Father André Scrima (d. 2000), Father Adrian Făgețean (d. 2011), Father Nicolae Bordașiu (d. 2018), Șerban Mironescu (d. 2008), Anton Dumitriu (d. 1992), Alexandru Elian (d. 1998), Alexandru Duțu (d. 1999), Virgil Cândea (d. 2007), etc. Even this is an incomplete list of only the better known members.

The failure of the disciples of this leaders to record the living members' testimonies may be pardoned, but concerned historians, social anthropologists, and researchers in general should not be let off so lightly. Moreover, the aforementioned leaders, as well as the previously deceased members, had close relatives and disciples who were still alive in the 1990s. Indeed, as of 2020, a few of these individuals still are alive. All these people were and still are remarkable sources for oral history, but they were hardly ever valued as such in a professional manner. Attempts to record these sources or to access available personal archives were made much later when many of the participants were much older and were experiencing health and even memory issues.

The truth is that serious research on the recent history of the ROC still had to wait in the first decade after the fall of communism. With a few notable exceptions, the general interest for this subject was rather modest. ${ }^{1}$

Research accuracy increased step by step, as the (political) leaders who were blocking or hindering the access to archives were pushed away from their leading positions or passed away. A similar evolution may be observed in all the research dedicated to our recent history. Let us remember that the greatest part of the former Security's (Ro. Securitate, the communist regime secret police) archives was only taken into custody by CNSAS (The National Council for the Study of Security Archives) in 2005, by means of a political decision, after Romania had joined NATO (2004) and in preparation of Romania's joining the EU (2007).

The documents in the ROC archives regarding the Burning Bush and its members' lives are still unavailable to all researchers. What has been published until now is just an important first step, but it is not enough. Especially in the past decade, professional studies were published, some of them based on $\mathrm{PhD}$ dissertations.

\footnotetext{
${ }^{1}$ The most notable endeavour is the work of Mrs. Anca Manolescu, to whom we owe the editing of the most precious book dedicated to our topic: André Scrima, Timpul Rugului Aprins (Bucharest: Humanitas, 1996). This seems to be the exception that proves the rule. For this study, we use the $3^{\text {rd }}$ edition (Bucharest: Humanitas, 2012).
} 
The documentation on the Burning Bush is still in its first stages. There are three main sources that may and must be put together for a complex view on the topic: (1) the participants' writings and testimonies, (2) testimonies from their disciples, friends and families, and (3) documents kept in various archives (ROC, CNSAS, The National Archives, private archives, etc.).

The works written by the members of the Burning Bush are only now being professionally edited. We note here the writings of Father Dumitru Stăniloae ${ }^{2}$ : an author series is currently being published at Basilica Publishing House and has reached the thirteenth volume. Another series, dedicated to Father André Scrima, now comprises seven volumes (Humanitas Publishing House). A handful of Burning Bush personalities, especially Father Dumitru Stăniloae, received special attention as their writings were analysed in $\mathrm{PhD}$ theses, both by Romanian and international theologians and researchers. Likewise, Father André Scrima's works seem to be just as much appreciated. We will now refer to the studies dedicated to his life and works.

Around 1989, André Scrima was practically unknown or, even worse, he was largely misunderstood by most theologians and those interested in spiritual life in Romania. His spectacular international career was more of an obstacle at home. Conservative circles used to accuse him (as they had done even before 1989) of being a "filo-Catholic," a "Freemason," and an "ecumenist." The files dedicated to him at CNSAS ${ }^{3}$ prove that André Scrima, who had left the country for a scholarship and thus escaped imprisonment, never betrayed his country, nor his church, not even when at the culmination of his career, he became a close counsellor of Athenagoras, the Ecumenical Patriarch, and a moderator in the talks between Constantinople and the Vatican in the 1960s. His role in the ecumenical dialogue was exploited and misrepresented by the political police and thus great slander and numerous lies were poured into the Orthodox clergy's discourse and into the Romanian public space, some of which persist to this day.

In the mid-90s, Father André Scrima returned to Romania, and for a few intellectuals who later on became his disciples, he represented a cultural and spiritual revelation. His presence bore unaltered the living Spirit of the Burning Bush...

But even so, problems persisted: for as long as he lived, his way of life - an itinerant monk, a category that has almost gone extinct nowadays -,

\footnotetext{
${ }^{2}$ I have proven on other occasions that, despite his own statements, Father Dumitru Stăniloae may be deemed a member of the Burning Bush, even if a marginal one, see: Marius Vasileanu, "Părintele Dumitru Stăniloae și Rugul Aprins," Magazin istoric 53/6 639, no. 53/6 (June 2020): 84-87.

${ }^{3}$ See the CNSAS archives, the SIE department, file number 2601.
} 
his elevated discourse, his familiarity with both Orthodox and universal spirituality, on the one hand, and with high culture in general (arts and sciences), on the other hand, created further obstacles for those who were not accustomed to this type of open-mindedness. Hence, new forms of reluctance on behalf of the ROC clergy, and sometimes even groundless accusations.

But, as it happened with the reception of the entire phenomenon of the Burning Bush throughout the past three decades, André Scrima's personality gradually came to be accepted. His remarkable works are now being taken care of by an editing team (most of which were his disciples) and are now being published in a scientific edition ${ }^{4}$. His life and works are now being analysed in their true essence, purified from the misinformation and the slander deliberately issued by the former political police. Nowadays, the reception of his personality has reached a tonic level, that can only nourish our optimism: a few $\mathrm{PhD}$ dissertations have been dedicated to him (some are still in preparation), several national and international conferences are aimed at discussing issues related to his life and works, a number of volumes on this topic have been published even abroad (e.g. in France, Canada, USA) 5 .

Father André Scrima's reception in the official ROC environment has also changed: special TV shows, conferences and studies have been dedicated to him. There is no such thing as a romantic, sweetened perspective, since Father André Scrima had a puzzling behaviour, some reluctance may still be felt, especially on behalf of the older generation and the more conservative orthodox clerics and laypeople.

But the best is yet to come. Two decades after his death, Father André Scrima is currently being recommended by young orthodox theologians, even by professors, as an important study topic. There are signs that the new generation of theologians has moved beyond slander and is more receptive

\footnotetext{
${ }^{4}$ The series André Scrima comprises: Antropologia apofatică (Bucharest: Humanitas, 2005); Biserica liturgică, trans. Anca Manolescu (Bucharest: Humanitas, 2005); Comentariu integral la Evanghelia după Ioan, trans. Anca Manolescu and Monica Broșteanu (Bucharest: Humanitas, 2008); Experienţa spirituală şi limbajele ei, edited by Anca Manolescu and Radu Bercea (Bucharest: Humanitas, 2008); Ortodoxia și încercarea comunismului, trans. Lucian Petrescu, Vlad Alexandrescu, and Miruna Tătaru-Cazaban (Bucharest: Humanitas, 2008); Funcţia critică a credinţei, ed. Anca Manolescu (Bucharest: Humanitas, 2011); Timpul Rugului Aprins, $3^{\text {rd }}$ edition, ed. Anca Manolescu (Bucharest: Humanitas, 2012).

${ }^{5}$ We are now referring to the following books: André Scrima, L'Évangile de Jean. Un commentaire, ed. Anca Vasiliu (Paris: Les Édition du Cerf, 2017); André Scrima, Passion et Résurrection selon Saint Jean, ed. Anca Vasiliu (Québec: Éditions Anne Sigier, 2007); André Scrima, Apophatic Anthropology, an English translation from Romanian by Octavian Gabor (New Jersey: Gorgias Press, Piscataway, 2016); André Scrima, L'accompagnamento spirituale. Il movimento del Roveto ardente e la rinascita esicasta in Romania, edizione italiana a cura di Adalberto Mainardi (Magnano, Comunità di Bose: Qiqajon, 2018).
} 
to authentic living in Christ, even if this is framed by a discourse that is still unusual in the Romanian Orthodox environment.

In the end, I will just add that, as in the case of Constantin Noica, Mircea Eliade, etc., among the young scholars, a few notable researchers have published studies that are at least just as valuable as those written by the Father's disciples ${ }^{6}$.

The same line of evolution, though not as spectacular, may be observed in the reception of the works written by other important members of the Burning Bush, who are still waiting for their analysts and readers willing to seek their inner self.

\section{The atmosphere at the Antim monastery}

Since the inter-war period to this day, the Antim monastery has had the (first informal, then, since 1950, official) status of a patriarchal chapel. In the 1940s, when the members of the Burning Bush used to meet at Antim, it was a privileged space, not only due to its history and its central location in Bucharest but also due to the intellectual quality of the monastic community. The 1940s abbot, Father Vasile Vasilache, notes in his memoirs the fact that many monks at Antim were studying various subjects at the university, not only theology ${ }^{7}$. For instance, André Scrima went to four faculties, and other brothers used to attend classes at two faculties, though they would not always finish their studies and be awarded bachelors degrees. Some of them would go on further for doctoral studies. The intellectual atmosphere at Antim was still vivid in the first years of the communist regime: people who have gone unnoticed in Romania and who remember their visits to Brother André Scrima's cell or even took part at the meetings of the Burning Bush are now well-known personalities in their areas of research ${ }^{8}$.

In the preface to the volume Timpul Rugului Aprins, Andrei Pleșu notes the main characteristics of the volume and of André Scrima's writings in general, characteristics that, in my opinion, are to be found in different proportions in the works of other members of the Burning Bush (I shall add their names between brackets): innovative language (Daniil Sandu Tudor, Paul Sterian, Mihail Avramescu), pairing again the theological discourse with a cultural metabolism (Tit Simedrea, Antonie Plămădeală, Alexandru Mironescu, Daniil Sandu Tudor, Ștefan Todirașcu, Benedict

\footnotetext{
${ }^{6}$ In this line, we recommend Ioan Alexandru Tofan, André Scrima și fizionomia experienței spirituale (Bucharest: Humanitas, 2019).

${ }^{7}$ Vasile Vasilache, De la Antim la Pocrov. Mărturii (Bucharest: Eikon, 2015), 47.

${ }^{8}$ For instance: Valentin Poenaru, professor of mathematics at Université de Paris-Sud. André Scrima mentions his friend in Timpul Rugului Aprins, 180-81.
} 
Ghiuş, Paul Sterian, Vasile Voiculescu, Alexandru Elian, Dumitru Stăniloae, Ion Marin Sadoveanu, Paul Constantinescu, Mircea Vulcănescu, Anton Dumitriu, Olga Greceanu, Petroniu Tănase, Gheorghe Dabija, Constantin Joja, Mihail Avramescu, Alexandru Duţu, Virgil Cândea, Virgil Stancovici), inter-confessional and inter-religious openness (Benedict Ghius,, Daniil Sandu Tudor, Mihail Avramescu, Anton Dumitriu, Ștefan Todirașcu, Paul Sterian, Alexandru Mironescu, Virgil Cândea).

We want to emphasize here that André Scrima is a brilliant representative of a certain atmosphere (generated by the Romanian inter-war intellectuals), of a monastic community and of an incredibly open ecclesiastic policy. Moreover, Father André Scrima was part of a spiritual practice group, the Burning Bush. All these represent the fertile seeds out of which his spiritual, intellectual and professional achievements would grow.

But the experience of the Burning Bush meant something more to those who constituted the core of the group. They received a certain spiritual inheritance, a mysterious one, and benefited from an effective transmission (paradosis) of the hesychast prayer. This is the topic of the volume Timpul Rugului Aprins, and of other writings by Father André Scrima.

As for Father André Scrima's inter-religious and inter-confessional openness, we must add that he was not the only one. Several of his closest friends, who were also part of the core of the Burning Bush, felt and thought likewise: Pr. Benedict Ghius,, Pr. Daniil Sandu Tudor, Vasile Voiculescu or Alexandru Mironescu. I shall no longer dwell on the topic; I shall just mention that all of them went through events that brought new spiritual horizons.

For instance, Tit Simedrea, a personality whose life and works have received too little attention, was in the 1920s-1930s the mentor of the young journalist Sandu Tudor and of other students who would later join the Burning Bush (Mircea Vulcănescu, Paul Sterian) and who were initially part of The Romanian Christian Students' Association (Asociația Studenților Creștini Români, hence ASCR) ${ }^{9}$. Tit Simedrea, represented the ROC at a pan-orthodox conference held on the Holy Mountain, at the Vatopedu monastery, in $1930 .{ }^{10} \mathrm{He}$ became the Metropolitan of Bucovina (19401945). Tit Simedrea hosted a meeting, called "Seven Days of Vigil" (1-7

\footnotetext{
${ }^{9}$ For the relation between ASCR and Tit Simedrea and the development of ecumenical relations by the members of the Burning Bush, see: Marius Vasileanu, "Mișcarea Rugul Aprins și dialogul interconfesional," in Paradisul regăsit. Studii ecumenice, ed. Alin Tat (Cluj Napoca: Ed. Napoca Star, 2017), 213-36.

${ }^{10}$ At this pan-orthodox pre-council synod (8-23 June, Vatopedu monastery, Mount Athos), the ROC was represented by Lucian Triteanu, the Bishop of Roman, and Tit Simedrea, Vicar Bishop of Bucharest at the time. The latter was sent on similar missions by the ROC to Lausanne (1927), Sofia and Istanbul (1929).
} 
August 1943, Cernăuți). The foundation of the Burning Bush was a natural follow-up. Tit Simedrea attended discreetly the group's meetings.

We can't tell if Father Scrima had learned from Tit Simedrea the details of the pan-orthodox meeting at Vatopedu or from other sources. In 1963, after his participation in the ceremonious anniversary "A Millennium of the Holy Mountain," Father A. Scrima noted:

Athos was the place that - need we remind it? - hosted in 1930, at the Vatopedu monastery, an orthodox pre-council (with no follow-up at that time, an attempt to resume it occurred only in 1961 in Rhodos), where the ROC delegation presented a project for an institutionalised permanent pan-orthodox council around the Ecumenical Patriarch. ${ }^{11}$ (own translation)

In 1929, Sandu Tudor, who would later on become Father Daniil, visited Mount Athos. During this pilgrimage, he noted the spiritual words of Antipa Dinescu, a former abbot of the Prodromu Romanian skete. His words were later quoted by André Scrima in a special moment. During the meeting between Pope Paul VI and Athenagoras, the Ecumenical Patriarch, held in June 1967 at Istanbul, André Scrima, who was a mediator, told the Pope about the prophetic words of Father Antipa Dinescu, namely: "Until the time of the anathema issued against you by your brother has passed, you will forget about yourself, you will crucify yourself for him, you will suffer in your heart - so that in the end, the in imaginable light of the Ressurection would shine again for both of you" (our translation). The anathemas had already been solemnly lifted (7 December 1965, Jerusalem), and this time the Pope kneeled in St. Sophia cathedral, in a certain place, and asked for forgiveness again and again... ${ }^{12}$

\section{A different kind of fool for Christ}

Though foolishness for Christ is a phenomenon that has occurred in Romanian Orthodoxy quite rarely, it has been seriously studied in Romania ${ }^{13}$, as well. Obviously, one must distinguish between foolishness for Christ (or

\footnotetext{
${ }^{11}$ See: André Scrima, Despre isihasm, ed. Anca Manolescu (Bucharest: Humanitas, 2003), 263. We can notice a constant preoccupation of Romanian Orthodox ecclesiastical diplomacy: at the Crete Pan-Orthodox Council (June 2016), the ROC delegation resumed the idea that such meetings should be held periodically (every 5-7 years).

${ }^{12}$ More details in Scrima, Timpul Rugului Aprins, 154, footnote.

${ }^{13}$ Especially by Cătălina Velculescu, Nebuni întru Hristos (Bucharest: Paideia, 2007), a volume dedicated to the lives of Simon Salos and Andrew Salos, as illustrated in old Romanian manuscripts and prints, and Cătălina Velculescu, "ARS BENE MORIENDI dans un écrit du Xe siècle et ses traductions roumaines," Simposia. Caiete de etnologie și antropologie (2004), 245-52. See also: Teodor Baconschi, Râsul patriarhilor (București: Anastasia, 1996).
} 
holy folly) and other forms of nonconformist Christian behaviour, such as 'the Christian idiot', or non-Christian one, e.g. the buffoon, the trickster. The latter are special types well represented in literature, for instance in the works of Erasmus, Cervantes, and Dostoevsky etc., and analysed by Hans Urs von Balthasar. ${ }^{14}$ However, we will not take these into account, as literary works fall outside the scope of our analysis, although spiritual folly has been a source of inspiration for some of the best literature writers in the world (from Dostoevsky and Wolfram to Grimmelshausen and Vodolazkin).

Of course, not every nonconformist Christian may be deemed a fool for Christ. According to the biography published in the report pleading for his canonization ${ }^{15}$, Father Arsenie Boca performed miraculous deeds, by power of his prayers, and those deeds were a proof of the presence of the Holy Spirit. But nevertheless, he totally obeyed his Orthodox superiors, throughout his entire life. His real, little-known biography records no gestures or manifestations based on which he could be deemed a fool for Christ. Father Arsenie Boca (1910-1989) was probably a saint who continues performing miracles to this day, but whose life sought 'the Imperial Way': he had a lifestyle adopted by most monks and mystics in the oriental Christianity. That's why he was often compared to St. Nectarios of Aegina or, in western Christianity, to Padre Pio.

The phenomenon of foolishness for Christ has an attractive history. It is based on two well-known sayings of Apostle Paul: "Let no man deceive himself. If any man among you seemeth to be wise in this world, let him become a fool, that he may be wise. For the wisdom of this world is foolishness with God" (1 Cor. 3.18-19) and "We are fools for Christ's sake" (1 Cor. 4.10) ${ }^{16}$. But there are antecedents and parallel manifestations just as attractive in other authentic religious traditions (e.g. in Judaism, in Zen Buddhism, in Islam) and even in folk literature, be it Western (e.g. the clown, the mime) or Oriental (e.g. Nasreddin Hodja).

The first example of a holy fool (gr. salos) recorded in Christian literature is a nun that lived in the $4^{\text {th }}$ century in the Egyptian monastery of Tabennesi: "as a form of extreme humility, she willingly puts on the mask of 'the fool' and of 'twisted minded', and her sisters in God treat her in the

\footnotetext{
${ }^{14}$ Hans Urs von Balthasar, Slava lui Dumnezeu. O estetică Teologică, vol. V, În spațiul metafizicii: Epoca modernă, trans. Maria-Magdalena Anghelescu (Bucharest: Galaxia Gutenberg, 2020), 129-230.

${ }^{15}$ Adrian Nicolae Petcu, "Părintele Arsenie Boca (o biografie documentară)," in Cuviosul Părintele nostru Arsenie Boca de la Sâmbăta de Sus și Prislop. Contextele și formele unei sfințenii, ed. Laurențiu Streza (Sibiu: Editura Andreiană, 2018), 41-164.

${ }^{16}$ Quoted from 21st century King James Version.
} 
least Christian way." ${ }^{17}$ There is also a monk with a similar lifestyle, Simon, who lived in Syria in the $6^{\text {th }}$ century. He is depicted in a number of writings, some of which are apocryphal. In exceptional circumstances, Simon's holiness is hidden behind the mask of folly, due to his humility. He is considered "a fool," and so he can trigger wonder in the people around him by making several controversial gestures whose real meaning will be revealed later on. Thus, he turns upside down the stalls at the church entrance and unmasks the hypocrites who pretend that they attend the service for faith etc.

The analysis of the holy folly in western Christian literature has been performed by two types of researchers. The first is represented by those born into the Orthodox faith or people who have converted to Orthodoxy, such as Kallistos Ware. ${ }^{18}$ The second group is comprised of researchers who belong to the Catholic faith or to other denominations, or laypeople. Among these, the better known individuals are Jesse Perillo ${ }^{19}$ and Rowan Williams ${ }^{20}$, who mix church history with literary fiction (e.g. Dostoevsky); therefore their works have little impact on our endeavour.

The typical fool for Christ, as it emerges from the research on the topic, is a modest character, with no intellectual skills or formal education, who achieves a certain knowledge by the power of the Holy Spirit. He or she then unveils (sometimes brutally) the hypocrisy and the sins of those who claim to be Christians. Some of these saloi get to behave aggressively - see the analysis of Ovidiu Olar. ${ }^{21}$ In the Byzantine Empire, however, the phenomenon became so commonplace, that holy fools could no longer be distinguished from "real fools." Therefore, in 692 the Quinisext Council ('in troullo') banned this behaviour. The holy folly was diminished in the Byzantine Empire - and eventually disappeared with the fall of the empire - , but it continued until the $20^{\text {th }}$ century mostly in the Slavic space. This is where it was also researched. In the $20^{\text {th }}$ century, a series of Russian authors dedicated numerous studies to it: Ioan Kovalevsky, Michel Evdokimov, Serghei A. Ivanov etc. In the works of Michel Evdokimov ${ }^{22}$, the distinction

\footnotetext{
${ }^{17}$ Velculescu, Nebuni, 12-13.

${ }^{18}$ Kallistos Ware, The Inner Kingdom. The Collected Works. Vol. 1: The Fool in Christ as Prophet and Apostle (Crestwood, New York: St. Vladimir's Seminary Press, 2000).

${ }^{19}$ Jesse Perillo, "The Prophetic Without Power and Disruption Without Direction: The Witness of Holy Fools," Journal of Society of Christian Ethics 36, no. 1 (January 2016): 145-62.

${ }^{20}$ Rowan Williams, "Holy Folly and the Problem of Representing Holiness: Some Literary Perspectives," Journal of Orthodox Christian Studies 1, no. 1 (August 2018): 3-15.

${ }^{21}$ Ovidiu Olar, "Abbas Moros. Violent Gestures between Brutality and Desire of Healing," Archaeus. Studies in the History of Religions 10, no. 3 (2006): 47-79.

${ }^{22}$ Michel Evdokimov, Pèlerins russes et vagabonds mystiques (Paris: Les Éditions du Cerf, 1987).
} 
between holy fools and mystical vagabonds is blunt. Serghei $\operatorname{Ivanov}^{23}$ has a more accurate diachronic perspective on the phenomenon, with sharp distinctions and multiple particularities. Indeed, these manifestations make up a complex mosaic, where each monk or nun adopts his own particular interpretation of the above-quoted Pauline verses ${ }^{24}-$ or at least that's how it seems to a layman.

But the aforementioned verse in 1 Cor. 4.10 goes on saying: "We are fools for Christ's sake, but ye are wise in Christ; we are weak, but ye are strong; ye are honorable, but we are despised," which brings further nuances. This verse - and the entire context in 1 Corinthians - has been the source of many other monastic manifestations that seek a complete rejection of the outside wisdom. The oriental Christian mentality lays a strong emphasis on the apparently sharp distinction between worldly knowledge, i.e. lay sciences and culture, and spiritual knowledge. ${ }^{25}$ Hence, the real and sometimes excessive contempt for knowledge in general, be it lay or theological.

Thus, foolishness for Christ seeks an answer to this problem: supramundane vs. mundane knowledge (to the latter theological learning is abusively added). ${ }^{26}$ Even if numerous church personalities raised above this dichotomy, the problem still needs concrete contemporary solutions. The solutions found by Romanian monks and nuns are illustrated in the volumes published by Ioanichie Bălan ${ }^{27}$, with a few meaningful exceptions.

The life and works of Father André Scrima represent a special answer to the problem.

We know from our everyday experience that people who took part in historical events or merely peaked in their careers change: their behaviour is temporarily or permanently altered by the "importance" of the office they once held. If we think of Father André Scrima's part in the reconciliation

\footnotetext{
${ }^{23}$ Serghei Ivanov, Sfinții nebuni întru Hristos, o perspectivă istorică, trans. Dorin Garofeanu (Iași: Doxologia, 2019).

${ }^{24}$ A common-sense observation made by Velculescu, Nebuni, 10.

${ }^{25}$ Irénée Hausherr S.J., Direction spirituelle en Orient autrefois, Orientalia Christiana Analecta 144-145 (Rome: Pont. Institutum Orientalium Studiorum, 1955), 89.

${ }^{26}$ Even Maximus the Confessor, whose erudition is well known, used to say with humility that he refuses the outside wisdom and pleaded for divine contemplation instead. Maxim Mărturisitorul, Ambigua, PSB 80, trans. Dumitru Stăniloae (Bucharest: Editura Institutului Biblic și de Misiune al Bisericii Ortodoxe Române, 1983), 215.

${ }^{27}$ In Ioanichie Bălan, Patericul românesc (Roman: Editura Episcopiei Romanului, 2001), 408-9, there is some information about a few monks that might be assimilated to our topic, such as the hermit Gherasim the Fool for Christ at the Neamț monastery (19th century). But Moș Gheorghe Lazăr (1846-1916), who was recently canonized (2018) under the name Gheorghe Pelerinul (i.e. the pilgrim), is one of the typical cases of mystical wanderer, not a fool for Christ.
} 
between Catholicism and Orthodoxy, at first glance that would be enough of an explanation for his puzzling behaviour and his lifestyle.

However, we seem to be missing something. We know that Father André Scrima didn't usually wear his monastic clothes, but at his funeral, the Romanian Patriarch came himself (without notice) and had his remains dressed in appropriate monastic attire. He was criticized for not having rejoined the monastic community at the Antim monastery after his return to Romania, but few know that he used to serve and take confessions there. In a nutshell, Father Scrima was completely nonconformist. For instance, he spoke to different persons about his birth year, mentioning three different dates (1926, 1927 and 1930), although documents support the fourth, the real one (1925). ${ }^{28}$ Andrei Pleșu described him as follows:

He recites long fragments by Djalâl ed-Dîn Rûmî and by Rilke, by Emily Dickinson and by Ion Barbu, from the Upanishads and from the Gospels. He takes delight in some pittoresque rare and old autochthonous words, but he speaks with a stylish French accent. He invokes astrophysics, modern genetics and topology as well as mastered domains, hums Russian songs and ends his phone calls with an Arabic phrase. ${ }^{29}$ (own translation)

In their attempt to understand him and to somehow label him, a great part of his close friends and disciples wrote or spoke about Father André Scrima as The Stranger. This label comes as no surprise as one of his life-changing events was the meeting with Father John the Stranger, a Russian monk who had fled the USSR and was hosted for a while at the Cernica monastery (1943-1946). Father Scrima ${ }^{30}$ and some of his closest disciples ${ }^{31}$ wrote brilliant pages about this wonderful meeting and about The Stranger. We are not going to argue against this apprehension of Father Scrima as The Stranger, but we would like to complete this perspective...

We believe that Father Scrima's puzzling behaviour was a manifestation of his foolishness for Christ. We have tried to identify the type of fool for Christ that he belonged to. In this attempt, we have searched the main categories of foolishness for Christ described by Hans Urs von Balthasar and Serghei Ivanov who mainly refer to Western and Eastern manifestations. It was in vain. In vain we have searched the most recent studies dedicated to

\footnotetext{
${ }^{28}$ Radu Bercea, "Peregrinarea lui André Scrima," in André Scrima. O gândire fără țărmuri, ed. Anca Manolescu (Bucharest: Humanitas, 2005), 117.

${ }^{29}$ Scrima, Timpul Rugului Aprins, 6.

${ }^{30}$ Ibidem, 36.

${ }^{31}$ E.g. Anca Vasiliu, "André Scrima, străinul," in André Scrima. O gândire fără țărmuri, $11-23$.
} 
this topic in the Catholic or Orthodox environment. We were unable to find in these books a similar type. And the reason underlying this failure is determined, most likely, by time. Most of the fools for Christ lived centuries ago. Or perhaps we do not know how to identify their present-day manifestations?

Our hypothesis is that André Scrima had a different relationship with time: for him, time was the Time of the Revelation. This is why he styled his book Timpul Rugului Aprins (Eng.: The Time of the Burning Bush), a title that should be understood as "The Time of that Burning Bush" (Exod. 3.12). The term was likewise understood by the Burning Bush group. Father Scrima emphasized that the term as referring to eternity: "The Burning Bush is not a literary or political invention: it comes from the originary horizon of the Revelation" ${ }^{2}$ (our translation).

What is the mission of a fool for Christ? To provoke wonder, and then metanoia. Heidegger defines it as follows: "wonder is that disposition of mind in which and for which the Being of what exists opens up"33 (our translation from Romanian). The Church Fathers speak about various ways of achieving humility, some of which are thought by the spiritual guide, in order to bring back the disciple on The Way of Life for Christ. St. Gregory Palamas (among others) shows that only a direct experience can get one to understand this spiritual endeavour. ${ }^{34}$

To whom did illo tempore the Fools for Christ address? They addressed the ordinary people, who were illiterate, but also to the few scholars or to the leaders of the cities, just like the prophets in the Old Testament had done before, but putting forth a discourse and behaviour that were more appropriate for their times. The fools' speech often comprised prophetic phrases and was accompanied by radical personal manifestations, which were, in a nutshell, completely nonconformist.

We believe that the 'character' André Scrima ('character' because his speech had a demonstrative tone) represents the anticipation of a different fool for Christ. In other words, André Scrima the man was so much of a nonconformist that even foolishness for Christ had to extend its limits to encompass a new type and thus adapt to postmodern culture and perhaps to the future.

To whom could this new kind of fool for Christ address? Let us notice his closest disciples' academic formation and professional path. After

\footnotetext{
32 Scrima, Timpul Rugului Aprins, 181.

${ }^{33}$ Quoted in Anton Dumitriu, Philosophia mirabilis. O incercare asupra unei dimensiuni necunoscute a filosofiei grecești (Bucharest: Editura Fundației Culturale Române, 1992), 28.

${ }^{34}$ Sf. Grigorie Palama, in Filocalia, vol. 7, trad. Dumitru Stăniloae (Bucharest: Editura Institutului Biblic şi de Misiune al Bisericii Ortodoxe Române, 1977), 277.
} 
returning to Romania, Father Scrima could have withdrawn in the mountains as a hermit, as he had previously done before leaving the country (in the Neamț area). Or he could have joined the monastic community in central Bucharest (at Antim). But he chose to remain an itinerant monk. The apartment he rented in a modest building in Bucharest (on Caragea Vodă street) became his cell in which he was visited for private seminars by Anca Manolescu (a mathematician and religious anthropologist), prof. Andrei Pleșu (philosopher, art historian, writer), Horia-Roman Patapievici (physicist, philosopher, writer), prof. Virgil Ciomoș (philosopher, psychoanalist), etc. Moreover, Father Scrima was surrounded by young postdoctoral fellows and alumni of the New Europe College (Bucharest), during the seminars and conferences he delivered in this institution for advanced studies. His lifestyle proposes a different way of bringing Christ in the City, a nonconformist manner of itinerancy, and gives a gorgeous lesson of valuing learned laypeople. Moreover, it is an exemplary expression of "pneumatic realism."

But, most of all, Father André Scrima seems to address the future. Humanity will have to face great challenges such as massive robotization, genetic engineering, neurosciences, the rapid development of artificial intelligence etc. How can these challenges be met? The answers of this different type of fool for Christ spring from a dazzling interdisciplinary culture, brilliant and sometimes baroque hermeneutics, from his ability to have, at the same time, a bird's eye view and in-depth knowledge of religious studies, arcane disciplines, and the philosophy of science. He had the audacity (parrhesia) to approach the most delicate topics in Christianity but at the same time a gentle reverence before the sacraments. In mathematical terminology, such a fool for Christ is an attractor that offers you the chance of spiritual guidance and leads you to your best personal asymptote within the Spirit.

To conclude, Father André Scrima seems to be telling us: I feel at home everywhere, the Center is everywhere, for it beats continuously in the heart of the hesychast.

Father André Scrima is the model of a fool for Christ for tomorrow's Christianity. 